\title{
Relationship between serum total cholesterol and progesterone levels and the number of transferable embryos in superovulated Holstein heifers and cows
}

\author{
Oh Kyeong KweON ${ }^{1 *}$, Hitoshi ONO ${ }^{1}$, Hideo Yamashina ${ }^{2}$, \\ Noboru SeIKE ${ }^{3}$, Kazuki MoRI ${ }^{3}$ and Hiroshi KanagaWA ${ }^{4}$ \\ ${ }^{1}$ Department of Meat Animal Reproduction, Obihiro University of Agriculture and Veterinary \\ Medicine, Obihiro 080 (present address, Department of Theriogenology, \\ Faculty of Veterinary Medicine, Hokkaido University, Sapporo 060), \\ ${ }^{2}$ Hokkaido Agricultural Department Cooperation, Taiki 089-22, \\ ${ }^{3}$ Embryo Transfer Research Laboratory, Hokkaido District Office, \\ Snow Brand Milk Products Co., Ltd. Horonai 069-14 \\ ${ }^{4}$ Department of Theriogenology, Faculty of Veterinary Medicine, \\ Hokkaido University, Sapporo O6O Japan
}

\begin{abstract}
Summary. In an effort to find preselection criteria that can be used to show good ovarian response to superovulation treatment, the relationship between serum total cholesterol and progesterone levels and the number of transferable embryos that can be obtained per donor was investigated. Superovulation was induced by either PMSG or FSH in 106 Holstein heifers and cows between days 9 and 13 of the estrous cycle. Serum total cholesterol and progesterone were analyzed. Percentage of animals in which over 3 transferable embryos were obtained was significantly less in animals with serum total cholesterol level of less than $130 \mathrm{mg} / \mathrm{d} l$ as compared to the animals with $130 \mathrm{mg} / \mathrm{d} l$ and more. It was also found that percentage of animals in which no transferable embryos were obtained was significantly higher in animals with total cholesterol of less than $130 \mathrm{mg} / \mathrm{d} l$. Animals with progesterone level of less than $1.0 \mathrm{ng} / \mathrm{m} l$ did not produce over 3 transferable embryos. These results indicate that serum total cholesterol and progesterone levels may be used as a criteria to indicate good ovarian response to superovulation.
\end{abstract}

(Japan J. Anim. Reprod., 31, 231-234, 1985)

\section{Introduction}

Success of embryo transfer in cattle is dependent on the number of transferable embryos that can be obtained from one donor. At least 4 transferable embryos should be obtained per collection, and in addition, 6 to 7 transferable embryos are assumed to be the economic numbers obtainable per collection from a donor ${ }^{1)}$. Superovulatory treatment in cattle has been conducted since the $1940 \mathrm{~s}^{2)}$ and is now the method being routinely carried out. Nevertheless, the results of treatment are unpredictable and variable among in- dividuals. This problem can be solved by applying preselection cirteria to determine cows most likely to respond favorably to superovulation treatment. These criteria were investigated in the present study on the relationship between serum total cholesterol (T-CHO) and progesterone levels and the number of transferable embryos that can be obtained per collection.

\section{Materials and Methods}

One hundred-six Holstein heifers and cows, aged between 16 months to 12 years, were used as donors from March 1982 to June 1983. 
Superovulation was induced in all animals using 2,000-4,000 IU of PMSG (Teikoku-Zoki Co.) or $35-55 \mathrm{mg}$ of FSH (Denka Co.) between days 9 and 13 of the estrous cycle. $\mathrm{PGF}_{2 \alpha}$ (The Upjohn Co.) was given intramuscularly to induce luteolysis 2 days after gonadotropins injection. The amount of $\mathrm{PGF}_{2 \alpha}$ used were either 25 to $35 \mathrm{mg}$ one time or 10 to $15 \mathrm{mg}$ twice a day. The animals were then artificially inseminated 2 or 3 times with frozen semen at 12 hours interval following the end of estrus. The embryos recovered were classified as either transferable or non-transferable according to their morphological characteristics and whether the transferable embryos reached the expected developmental stage corresponding to their chronological age ${ }^{3)}$. Blood samples were collected from the coccygeal vein on the day of gonadotropins injection. Serum was separated and stored about $-20^{\circ} \mathrm{C}$ until analysis. T-CHO was analyzed spectrophotometrically by an enzyme method ${ }^{4)}$. Serum progesterone was analyzed by the method validated by MAKINO ${ }^{5)}$. The recovery rate and the assay sensitivity for progesterone was $91.3 \%$ and $0.19 \mathrm{ng} / \mathrm{m} l$, respectively. Intraand inter-assay coefficients of variation were 3.3 and $3.9 \%$, respectively. Animals were

Table 1. Relationship between serum total cholesterol level and the number of transferable embryos in superovulated Holstein heifers and cows

\begin{tabular}{ccc}
\hline \hline $\begin{array}{c}\text { Cholesterol } \\
(\mathrm{mg} / \mathrm{d} l)\end{array}$ & $130>$ & $130 \leqq$ \\
\hline $\begin{array}{c}\text { No. of animals } \\
\text { tried }\end{array}$ & 54 & 52 \\
No. of animals & & \\
with embryos & & \\
$\geqq 4$ & $7(13.0 \%)^{\mathrm{a}}$ & $25(48.1 \%)^{\mathrm{b}}$ \\
$1-3$ & $21(38.9 \%)^{\mathrm{a}}$ & $18(34.6 \%)$ \\
0 & $26(48.1 \%)^{\mathrm{a}}$ & $9(17.3 \%)^{\mathrm{b}}$ \\
\hline
\end{tabular}

Percentage with different superscripts in the same cow are significantly different $(P<0.01)$. divided into groups according to serum T-CHO $(130 \mathrm{mg} / \mathrm{d} l>, 130 \mathrm{mg} / \mathrm{d} l \leqq)$ or serum progesterone level $(1.0 \mathrm{ng} / \mathrm{m} l>, \quad 1.0-1.9 \mathrm{ng} / \mathrm{m} l, 2.0$ $\mathrm{ng} / \mathrm{ml} \leqq)$. Difference of the percentages between groups was evaluated by the $\chi^{2}$-test.

\section{Results}

The relationship between serum T-CHO level and the number of transferable embryos is shown in Table $1.13 .0 \%(7 / 54)$ of the while that had T-CHO level of less than $130 \mathrm{mg} / \mathrm{d} l$ $48.1 \%(25 / 52)$ of the cows that had $130 \mathrm{mg} / \mathrm{d} l$ and more produced more than 3 transferable embryos $(P<0.01)$. No embryos were obtained in $48.1 \%(26 / 54)$ and $17.3 \%(9 / 52)$ of animals having less than $130 \mathrm{mg} / \mathrm{d} l$ and 130 $\mathrm{mg} / \mathrm{d} l$ and more, respectively $(P<0.01)$. The relationship between the progesterone level

Table 2. Relationship between serum progesterone level and the number of transferable embryos in superovulated Holstein heifers and cows

\begin{tabular}{cccc}
\hline $\begin{array}{c}\text { Progesterone } \\
(\mathrm{ng} / \mathrm{m} l)\end{array}$ & $1.0>$ & $1.0-1.9$ & $2.0 \leqq$ \\
\hline $\begin{array}{c}\text { No. of animals } \\
\text { tried } \\
\begin{array}{c}\text { No. of animals } \\
\text { with embryos }\end{array}\end{array}$ & 9 & 29 & 14 \\
$\geqq 4$ & $0(00.0 \%)^{\mathrm{a}}$ & $9(31.0 \%)$ & $8(57.1 \%)^{\mathrm{b}}$ \\
$1-3$ & $5(55.6 \%)$ & $10(34.5 \%)$ & $4(28.6 \%)$ \\
0 & $4(44.4 \%)$ & $10(34.5 \%)$ & $2(14.3 \%)$ \\
\hline
\end{tabular}

a,b $P<0.05$.

Table 3. Percentage of animals with more than 4 transferable embryos in relation to progesterone and total cholesterol

\begin{tabular}{cccc}
\hline \multirow{2}{*}{$\mathrm{T} \cdot \mathrm{CHO}$} & \multicolumn{3}{c}{ Progesterone $(\mathrm{ng} / \mathrm{ml})$} \\
\cline { 2 - 4 }$(\mathrm{mg} / \mathrm{d} l)$ & $2.0>$ & $2.0 \leqq$ & Subtotal \\
\hline \multirow{2}{*}{$130 \leqq$} & $25.0 \%$ & $87.5 \%$ & $45.8 \%$ \\
& $(4 / 16)$ & $(7 / 8)$ & $(11 / 24)$ \\
$130>$ & $22.7 \%$ & $16.7 \%$ & $21.4 \%$ \\
& $(5 / 22)$ & $(1 / 6)$ & $(6 / 28)$ \\
\hline Subtotal & $23.7 \%^{\mathrm{a}}$ & $57.1 \% \mathrm{~b}$ & \\
& $(9 / 38)$ & $(8 / 14)$ & \\
\hline
\end{tabular}

a,b $P<0.05$. 
and the number of transferable embryos is shown in Table 2 . Over 3 transferable embryos were obtained in $0.0 \%(0 / 9), 31.0 \%$ $(9 / 29)$ and $57.1 \%(8 / 14)$ in animals with a progesterone level of less than $1.0 \mathrm{ng} / \mathrm{ml}$, between $1.0-1.9 \mathrm{ng} / \mathrm{m} l$ and more than 2.0 $\mathrm{ng} / \mathrm{m} l$, respectively. This percentage was significantly lower in animals with a progesterone level of less than $1.0 \mathrm{ng} / \mathrm{ml}$ as compared to animals with a progesterone level of more than $2.0 \mathrm{ng} / \mathrm{ml}(P<0.05) .87 .5 \%(7 / 8)$ of animals with T-CHO of $130 \mathrm{mg} / \mathrm{d} l$ and more, and progestone of $2.0 \mathrm{ng} / \mathrm{m} l$ and more produced more than 3 transferable embryos (Table 3). This percentage was higher than those groups in which T-CHO level was less than $130 \mathrm{mg} / \mathrm{d} l$, with progesterone level of either more or less than $2.0 \mathrm{ng} / \mathrm{ml}$; or more than $130 \mathrm{mg} / \mathrm{d} l$, with progesterone of less than $2.0 \mathrm{ng} / \mathrm{ml}$.

\section{Discussion}

The relationship between ovarian response to hormonal treatment and parameters such as hormones ${ }^{6,7)}$, blood chemical components ${ }^{8,8)}$ and body characteristics ${ }^{10)}$ was investigated in order to see if any of these components could be used as criteria to predict superovulatory response in the donor. HAHN et al.$^{8)}$ mentioned that there is a possible relationship between serum T-CHO levels and ovarian response to superovulatory treatment. They reported that a high level of cholesterol $(121.4 \pm 17.1 \mathrm{mg} / \mathrm{d} l<)$ was found in heifers with undesirable superovulatory response. On the contrary, the results of present study indicated that the number of transferable embryos was higher in animals with T-CHO level of $130 \mathrm{mg} / \mathrm{d} l$ and more. The reason for this difference was not clear and needs further investigation. SOMMER ${ }^{11)}$, LOTTHAMMER et $a l{ }^{12)}$ and KWEON et $a l .{ }^{13)}$ reported that cows with a low cholesterol level before calving had a greater possibility of suffering diseases after calving as compared to the cows with a normal cholesterol level. It was found that the normal range of $\mathrm{T}$-CHO in dry cows was between $120 \mathrm{mg} / \mathrm{d} l$ and $170 \mathrm{mg} / \mathrm{d} l$. However, in the case of cows with peak daily milk of more than $30 \mathrm{~kg}$, the upper levels of the normal range seem to be higher ${ }^{13)}$. In the present study the normal range of $\mathrm{T}-\mathrm{CHO}$ was thought to be $130 \mathrm{mg} / \mathrm{d} l$ and more, based on the percentage of cows in which over 3 transferable embryos were obtained. Similar result was observed from the two different situations with respect to the occurrence rate of diseases after calving and the ovarian response to superovulation treatment. T-CHO level in cattle varies according to several factors such as parturition, lactation and occurrence of diseases ${ }^{14,15)}$. It was observed that cows which suffered diseases within 1 week after calving and showed symptoms such as anorexia, fever and pain had lowered T-CHO up to 10 weeks after calving ${ }^{15)}$. T-CHO is one of the metabolite which represent the condition of lipid metabolism of cattle ${ }^{18)}$. It is thought that cows with T-CHO of at least $120 \mathrm{mg} / \mathrm{d} l$ or $130 \mathrm{mg} / \mathrm{d} l$ and more may be healthy metabolically and that these cows produce good response to external stimulation. ELSAESSER et $a l^{\left.{ }^{b}\right)}$ reported that the milk progesterone level on the day of superovulation treatment was significantly correlated with the number of corpus lutea palpated through the rectum at flushing $(r=0.45)$. In the present study over a half of animals on luteal phase of the estrous cycle had less than $2.0 \mathrm{ng} / \mathrm{m} l$ of progesterone. A significant difference was observed between the animals which had a progesterone level below 1.0 $\mathrm{ng} / \mathrm{m} l$ and over $2.0 \mathrm{ng} / \mathrm{m} l$ which is used to 
determine the existence of active corpus luteum $^{17)}$. It was suggested that active corpus luteum in the ovary during superovulation treatment is an important factor to show good ovarian response ${ }^{18)}$. Elsaesser et $a l .^{\left.{ }^{6}\right)}$ suggested that the relationship between the responsiveness of the ovaries with respect to the stimulation of progesterone secretion and ovulation rate is mediated through some common mechanism. The present results revealed that animals with a T-CHO level of $130 \mathrm{mg} / \mathrm{d} l$ and more, and a progesterone level of $2.0 \mathrm{ng} / \mathrm{m} l$ and more showed good ovarian response to superovulation treatment. Hence this criterion can be used in preselection of the donor in embryo transfer procedures. Further studies and more observation are needed to confirm this finding.

\section{References}

1) Bowen JM: Current Theriogenology: diagnosis, treatment and prevention of reproductive diseases in animals. Morrow D.A., 1st ed., Saunders, p. 107, 1980.

2) Casida LE, RK Meyer, WH Meshan \& W WINSNICKY: Am. J. Vet. Res., 6, 76, 1943.

3) Kanagawa H: Embryo Transfer in Cattle. Kanagawa H., 1st ed., Kindai-shuppan, Tokyo, p. 63, 1984 (in Japanese).

4) Allain C, LS. Poon, CSG Chan, W Richmond \& PC FU: Clin. Chem., 20, 470, 1974.

5) MaKino T: Folica. endocr. Japonica, 49, 629,
1973.

6) Elsaesser F, B SACHer, P HAUPt, WV SCHUTZBAR \& D SMIDT: Zuchthygiene, 16, 193. 1981.

7) Monniaux D, D Chupin \& J Saumande: Theriogenology, 19, 55, 1983.

8) HahN J, R HahN, G BaUmgartner, KH LOTTHAMmeR, W LORRMANN, U SCHNEIDER, J TRAUB \& HF ZODER: Zuchthygiene, 12, 68, 1977.

9) Hahn J, J Traub, O Agathe, hP Koln \& KH LoTTHAMmer: 8th International Congress on Animal Reproduction and Artificial Insemination, p. 251, 1976.

10) CRitser JK, FC Gunsett, RF Rowe, JJ RUtLedGe \& OJ GintheR: Theriogenology, 11, 94, 1979.

11) Sommer H: Vet. Med. Rev., 112, 42, 1975.

12) Lotthammer KH, KV Benten \& HEL NAHS: Der praktische Tierarzt., 13, 563, 1971.

13) KWEON OK., H ONo, $\mathrm{T}$ Seta, M ONDA, $\mathrm{K}$ Oboshi \& H Kanagawa: Jpn. J. Vet. Res., 33, 17, 1985.

14) Kweon OK, H ONo, $\mathrm{K}$ Osasa, $\mathrm{K}$ Oboshi, $M$ Onda, H Kurosawa \& H Kanagawa: Jpn. J. Vet. Sci., 1986 (in Press).

15) KWEON OK, $\mathrm{H}$ ONo, $\mathrm{H}$ Yamashina \& $\mathrm{H}$ Kanagawa: J. Hokkaido Vet. Med. Assoc., 29, 7, 1985.

16) Kaneko JJ: Clinical Biochemistry of Domestic Animals. Kaneko J. J., 3rd ed., Academic Press, p. 16, 1980.

17) Kaneda Y, H Kamomae, I Domeki, K Nishikata \& T Nakahara: Jpn. J. Anim. Reprod., 27, 93, 1981.

18) BeCZe J, J MÉszáros \& I Periés: Zuchthygiene, 14, 26, 1979.

(Received April 30, 1985) 
ホルスタイン種乳牛における過剰排卵誘起時の血清総コレステロール および黄体ホルモン值と移植可能な肧数との関係

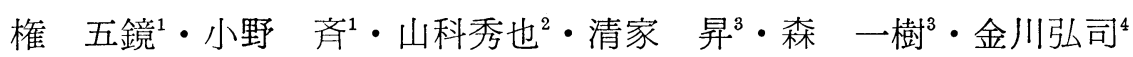

( ${ }^{1}$ 帯広畜産大学家畜生産科学科 ${ }^{2}$ 北海道農業開発公社 ${ }^{3}$ 雪印乳業 ${ }^{4}$ 北海道大学獣医学部)

過剩排卵処置に対する卵巣反応を予測する試みとし て, 過㮃排卵処置時の血清総コレステロールおよび黄体 ホルモン值と移植可能な胚数との関係を検討した。供試 牛はホルスタイン種乳牛 106 頭で過唾排卵誘起は性周期 の 9〜13 日の間に PMSG または FSH によって行っ
た。総コレステロール $130 \mathrm{mg} / \mathrm{d} l$ 未満の牛がそれ以上 の牛より 4 個以上の正常卵を得られる確率が有意に少な かった $(P<0.01)$ 。また, 正常卵を得られない確率も高 かった。黄体ホルモン值 $1.0 \mathrm{ng} / \mathrm{m} l$ 末満の牛では 4 個 以上の正常卵が得られなかった。 